\title{
ORAL MANIFESTATIONS OF SYPHILIS
}

\author{
Jair Carneiro Leão ${ }^{\mathrm{a}, \mathrm{b}}$, Luiz Alcino Gueiros ${ }^{\mathrm{a}}$, and Stephen R. Porter
}

Leão JC, Gueiros LA, Porter SR. Oral manifestations of syphilis. Clinics. 2006;61(2):161-6.

The past decade has shown a significant rise in the prevalence of infective syphilis in the developed world, and striking increases in its frequency have occurred in Eastern Europe, particularly the UK, and in the US. Although oral manifestations of syphilis are most likely to be observed during secondary disease, all stages of the disease can give rise to oral lesions. Significant oral lesions such as gumma-associated bony destruction and a possible predisposition to oral squamous cell carcinoma are associated with tertiary disease. Since the prevalence of infective syphilis in heterosexuals has been increasing, there has now been a gradual rise in the number of children born with congenital syphilis. Consequently, the congenital disease gives rise to dental anomalies as well as bone, skin, and neurological anomalies of the face. The aim of this report is to review syphilis-related oral lesions, as well as to summarize the relations between human immunodeficiency virus (HIV) and syphilis.

KEYWORDS: Syphilis. Congenital Syphilis. HIV. Communicable diseases.

\section{CHANGING EPIDEMIOLOGY OF INFECTIVE SYPHILIS}

Infective syphilis is caused by the anaerobic filamentous spirochete, Treponema pallidum. In the past decade there has been a significant rise in the prevalence of infective syphilis in the developed world. Striking increases in the frequency of syphilis have occurred in Eastern Europe, ${ }^{1-5}$ and smaller rises have been reported in Western Europe and the US. The changing epidemiology of syphilis reflects the falling use of barrier methods of contraception, ${ }^{6}$ high numbers of sexual partners, ${ }^{7}$ sexual promiscuity, ${ }^{8}$ lack of relevant knowledge, ${ }^{9}$ the sex industry, the health care breakdown in former Communist communities, and the deterioration of public health responses to sexually transmitted infection (STI) control (e.g. faster notification). ${ }^{2}$ In Eastern Europe, the increased frequency

\footnotetext{
a Department of Clinic and Preventive Dentistry, Federal University of Pernambuco

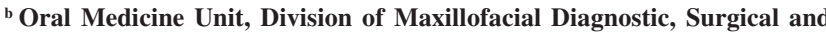
Medical Sciences, Eastman Dental Institute for Oral Health Care Sciences, University of London - London, UK.

Email : jleao@ufpe.br

Received for publication on 25 July, 2005.

Accepted for publication on December 05, 2005.
}

of syphilis has been predominantly in heterosexuals, while in the UK and US, the outbreaks have occurred in heterosexuals and in men having sex with men. ${ }^{6}$ Outbreaks in the US have sometimes been associated with the use of crack cocaine, and rapid spread of syphilis has occurred in prisons where recent arrestees may already be infected. ${ }^{10}$

\section{PRIMARY SYPHILIS}

The mouth, perhaps surprisingly, is rarely the site of primary syphilis, and because of its transient nature, the oral ulceration of primary syphilis often goes unnoticed by the patient or by any unsuspicious clinician. ${ }^{11}$ In addition, albeit rarely, the lesions of primary disease may be confused with other pre-existing mucocutaneous disease. ${ }^{12} \mathrm{~A}$ chancre develops within 1 to 3 weeks of acquisition. Primary syphilis is usually the consequence of orogenital or oroanal contact with an infectious lesion. Kissing may, very rarely, cause transmission; ${ }^{13}$ indeed, it has been suggested that intrafamilial oral acquisition of syphilis in a child may have occurred via this route, although more usually oral syphilis in a child is indicative of sexual abuse. ${ }^{14}$

Primary syphilis of the mouth manifests as a solitary ulcer usually of the lip or, more rarely, the tongue. The up- 
per lip is more commonly affected than the lower in males, while the opposite occurs in females-probably reflecting the anatomy involved with fellatio and cunninlingus. The pharynx or tonsils may rarely be affected. The ulceration is usually deep, with a red, purple, or brown base and an irregular raised border. There is usually an accompanying cervical lymphadenopathy. The ulceration of primary syphilis may be confused with other solitary ulcerative disorders, most notably traumatic ulceration, squamous cell carcinoma, and non-Hodgkin's lymphoma. ${ }^{15}$

The diagnosis of primary syphilis may be aided by detailed analysis of the sexual and/or social lifestyles of the patient and of any of the available sexual partner; however, often the diagnosis of early disease can be difficult. Affected patients often do not have a positive nonspecific reaginic test, eg, Rapid Plasma Reagin (RPR) or Venereal Disease Reference Laboratory (VDRL) tests. The specific tests for IgG antibodies to T. pallidum become positive before the reaginic tests, and thus should be carried out when the nonspecific tests prove negative but a diagnosis of primary disease is still likely.

Treponemes are present in primary lesions and can be detected by dark field microscopy; however, this test is fraught with the risk of nosocomial transmission and is thus no longer considered suitable. In addition, there can be confusion between the spirochetes of T. pallidum with the normal commensals of the mouth.

Histopathology is not always helpful, as there are no specific histopathological features, and the detection of $T$. pallidum with Warthin-Starry stain or silver nitrate stain may not be possible. Monoclonal anthodyl immunoperoxidase staining techniques can detect $T$. pallidum and is a relatively routine clinical investigation of biopsy material. However, molecular methods such as in situ and tissue PCR still remain nonroutine investigations for all types of syphilis. The tests used to detect IgM antibodies to T. pallidum may detect early infection.

\section{OUTCOMES OF THERAPY}

The primary chancres spontaneously heal within 7 to 10 days, although they can persist much longer, only resolving with appropriate antimicrobial therapy.

\section{SECONDARY SYPHILIS}

The features of secondary syphilis reflect the hematogenous spread of T. pallidum, and similarly to its other mucocutaneous features, the oral manifestations of secondary syphilis can be more extensive and/or variable than those of the primary disease. Oral lesions arise in at least $30 \%$ of patients with secondary syphilis, although very rarely oral ulceration may be the only manifestation of infection. The 2 principal oral features of secondary syphilis are mucous patches and maculopapular lesions, although nodular lesions may rarely arise.

\section{MACULOPAPULAR LESIONS}

- Macular syphilides: Macular lesions tend to arise on the hard palate and manifest as flat-to-slightly raised, firm, red lesions. ${ }^{16}$

- Papular syphilides: These are rare. They manifest as red, raised, firm round nodules with a grey center that may ulcerate. The papules usually arise on the buccal mucosa or commissures. ${ }^{17}$

- Mucous patches: A variety of descriptions of mucous patches have been reported, but in general these manifest as oval-to-crescenteric erosions or shallow ulcers of about $1 \mathrm{~cm}$ diameter, covered by a grey mucoid exudate and with an erythematous border. ${ }^{16}$ The patches usually arise bilaterally on the mobile surfaces of the mouth, ${ }^{18}$ although the pharynx, gingivae, tonsils, and very rarely the hard palate can be affected. ${ }^{19}$ At the commissures, the mucous patches may appear as split papules, while on the distal and lateral aspects of the tongue, they tend to ulcerate or manifest as irregular fissures. The mucous patches may coalesce to give rise to, or arise de novo as, serpiginous lesions, sometimes termed snail track ulcers. ${ }^{19-22}$

\section{ULCERONODULAR DISEASE (LUES MALIGNA)}

Ulceronodular disease is an explosive generalized form of secondary syphilis characterized by fever, headache, and myalgia, followed by a papulopustular eruption that rapidly transforms into necrotic, sharply demarcated ulcers with hemorrhagic brown crusts, organized in rupioid layers commonly on the face and scalp. The mucosa is involved in about one third of affected patients. Lues maligna gives rise to crateriform or shallow ulcers on the gingivae, palate or buccal mucosa, with multiple erosions on the hard and soft palates, tongue and lower lip..$^{23-25}$

\section{NODULAR DISEASE}

Rarely, secondary syphilis can manifest as nodules alone. This nodular eruption of syphilis has a predilection for the face, mucous membranes, palms of the hands and soles of the feet. ${ }^{26}$ Lesions may occur on the vermillion, mimicking squamous cell carcinoma or keratoacanthoma. 


\section{DETECTION OF INFECTION IN SECONDARY DISEASE}

Treponema pallidum can usually be detected on the surface of erosions or ulcers by darkfield microscopy, although as noted above, this test should be avoided. The patient will have positive serological tests.

The histopathological features of secondary syphilis are variable. Often the changes are nonspecific, although they may include perivascular infiltrates with a preponderance of plasma cells and epidermal psoriasiform hyperplasia. Warthin-Starry strains will only detect spirochetes in about a third of instances, although newer methods may increase the in situ detection of the causative agent.

\section{OUTCOMES OF THERAPY}

The lesions of secondary syphilis will resolve spontaneously within 3 to 12 weeks, regardless of therapy, and about $25 \%$ of untreated patients will have recurrence of secondary disease.

\section{LATENT SYPHILIS}

In early latent syphilis, usually the first 12 months after secondary disease, affected patients are infectious. In late latent syphilis the infectivity falls.

\section{TERTIARY SYPHILIS}

Clinical disease arises in about one third of patients with untreated secondary syphilis. The oral complications of tertiary syphilis center upon gumma formation, and much more rarely, syphilitic leukoplakia (and risk of oral squamous cell carcinoma) and neurosyphilis.

\section{GUMMA FORMATION}

Gummas tend to arise on the hard palate and tongue, although very rarely they may occur on the soft palate, lower alveolus, and parotid gland. ${ }^{27-30} \mathrm{~A}$ gumma manifests initially as 1 or more painless swelling. ${ }^{16}$ When multiple, they tend to coalesce, giving rise to serpigninous lesions. The swellings eventually develop into areas of ulceration, with areas of breakdown and healing. There may be eventual bone destruction, palatal perforation, and oro-nasal fistula formation. Rarely, a gumma may erode into blood vessels-eg, the inferior alveolar artery. Gumma manifests radiologically as illdefined radiolucencies that may resemble malignancy. The areas of ulceration eventually heal, although the resultant scarring can, at least on the tongue, cause fissuring.

\section{SYPHILITIC LEUKOPLAKIA AND RISK OF SQUAMOUS CELL CARCINOMA}

Syphilitic leukoplakia would appear to be a homogenous white patch affecting large areas of the dorsum of the tongue. There are few good descriptions of syphilitic leukoplakia, and it is unclear whether this lesion truly reflects syphilis, or more likely a tobacco smoking habit-indeed this was observed by Hutchinson in the 19th century.

An association between tertiary syphilis and oral squamous cell carcinoma — particularly of the tongue — has been suggested for many years. Both clinically- and serologically-based studies have suggested an increased prevalence of syphilis in patient groups with squamous cell carcinoma of the tongue (up to $60 \%$ in one study), the association being stronger in males than females. ${ }^{31}$ A relatively recent study of 16,420 people with syphilis resident in the US found a significantly raised frequency of cancer of the tongue (and Kaposi's sarcoma) in males. ${ }^{32}$ A noncontrolled study found that 5 of $63 \mathrm{UK}$ patients with squamous cell carcinoma of the tongue had serological evidence of past syphilis as detected by both specific and nonspecific tests. ${ }^{33}$ However, it remains unclear whether any risk of oral squamous cell carcinoma in syphilis is a direct consequence of infection (which seems unlikely) or is the effect of recognized causative factors for oral malignancy, ie, tobacco, alcohol, and malnourishment.

\section{NEUROSYPHILIS}

Aside from the well-recognized Argyll Robertson pupil, tertiary syphilis can give rise to both unilateral and bilateral trigeminal neuropathy and facial nerve palsy. ${ }^{34}$ Potentially, syphilitic osteomyelitis may give rise to trigeminal neuropathy.

\section{DETECTION OF INFECTION IN TERTIARY DISEASE}

Gummas are characterized histopathologically by endarteritis obliterans, necrosis with epithelioid and giant cells and a plasma cell infiltrate. Spirochetes are difficult to detect. In tertiary disease, the nonspecific tests may not be positive; the most reliable test is FTA, although this may remain positive even after successful therapy.

\section{CONGENITAL SYPHILIS}

As discussed previously, in some communities there is a rising prevalence of congenital syphilis. Treponema pallidum crosses the placenta only after the 16th week of 
intrauterine life; hence, depending upon the time of infection, it may variably affect the facial structures. Resembling its systemic features, the orofacial manifestations of congenital syphilis can be split into early and late. Early features include diffuse maculopapular rash, periostitis (frontal bossing of Parrot), and rhinitis. Late features, manifesting at least 24 months after birth, comprise the Hutchinsonian triad of interstitial keratitis of the cornea, sensorineural hearing loss, and dental anomalies.

The dental anomalies of congenital syphilis only arise in teeth in which calcification occurs during the first year of life, hence typically the permanent incisors and first molars. Of note, the maxillary incisors are more commonly affected than the mandibular ones. The incisors have a screwdriver shape, there being a convergence of the lateral margins towards the incisal edge. In some, there may be notching of the incisal edge, while in others, there may be a depression on the labial surface. The first molar may be bud-shaped and reduced to the size of the adjacent second molar. The normal mesiodistal convexity of the crown may be reduced. Enamel hypoplasia may occur. Yellow discoloration of the skin about the lips can arise soon after birth; the area then becomes increasingly rigid with crack formation and eventual (Parrot's) radial scars-rhagades_of the lips. There may be a loss of the well-circumscribed border of the vermillion.

Other, less common orofacial features include atrophic glossitis and a high, narrow palatal vault. Facial neuropathies may rarely occur as can palatal gumma in adulthood. ${ }^{35}$

\section{INTERACTIONS BETWEEN HIV AND SYPHILIS}

According to WHO, Brazil had about 660,000 people living with human immunodeficiency virus (HIV) at the end of 2003, and 15,000 people had died of AIDS during that year. Heterosexual transmission, sex between men, and injecting drug users (IDU) continue to be almost equally responsible for the burden of HIV infection. However, the HIV epidemic in Brazil has changed over the last decade, with IDU being responsible for almost $30 \%$ of all HIV cases.

Strong evidence supports several biologic mechanisms through which sexually transmitted diseases (STDs) facilitate HIV transmission by increasing both HIV infectiousness and HIV susceptibility. Thus, the detection of STDs and the establishment of effective treatment is an important strategy of HIV control. ${ }^{36}$

\section{INFLUENCE OF HIV DISEASE UPON SYPHILIS}

It was initially suggested that concurrent HIV infection and syphilis is not uncommon, particularly in young adults, men having sex with men, ${ }^{6}$ and traders of commercial sex. HIV disease might significantly influence the clinical source of syphilis, as it does for some STDs and other conditions related to HIV-associated immune deficiency, and the associated infection is often more aggressive than the mono-infection. ${ }^{6}$ A Nigerian study of 31 people with concurrent HIV infection and syphilis found that $64.2 \%$ of the patients had developed unusual lesions affecting more than $50 \%$ of the body. Also, the chancres seen at the sites of inoculation had an atypical appearance. ${ }^{37}$

However, a recent detailed study suggests that other than an increased number and frequency of genital ulcers in secondary disease, HIV disease does not greatly impact the clinical care of syphilis. Nevertheless, there have been reports of prolonged primary disease and secondary disease; additionally, neurosyphilis ${ }^{38}$ may present more quickly and ulceronodular disease is more likely in patients infected with HIV than in those not infected. ${ }^{39,40}$

\section{INFLUENCE OF ORAL SYPHILIS UPON HIV DISEASE}

Patients with concurrent HIV infection and syphilis usually have a history of sexually transmitted infection, and it is common that these patients have more than 1 condition (eg, genital ulcers, injected drug addition, etc) that are potential sources of exposure. ${ }^{37}$ The genital ulceration of syphilis increases the risk of HIV transmission. ${ }^{41}$ Nonulcerative STD, however, also have the capacity of increasing the likelihood of HIV transmission, ${ }^{42}$ and the detection and treatment of syphilis can probably help to reduce HIV transmission. ${ }^{43}$ While there are no data to support the notion, it is likely that oral syphilis principally influences HIV disease by increasing the likelihood of HIV transmission (and other related viruses) by oral sexual routes. A recent study found no association between early syphilis and changes in blood or semen viral load or CD4 count in HIV-positive individuals. According to the study, increased HIV-1 infectivity associated with early syphilis is unlikely to be associated with increased levels of HIV-1 RNA in blood or semen. There is now compelling evidence, based upon case and epidemiological studies, that HIV can be transmitted via orogenital contact. In addition, as persons in high-risk groups for HIV move away from highrisk sexual activities, there is likely to be an increased frequency of orogenital contact, and hence oral sex will contribute to a greater frequency of new infections than previously. Oral ulcerative disease, such as that of all the stages of syphilis, will increase the HIV load in the mouth, and hence the potential for HIV transmission via oral sex. ${ }^{44}$ In 
addition, this increased risk of HIV transmission will be further worsened by ulcerative disease secondary to the use of the recreational drugs, crack cocaine ${ }^{45}$ and cocaine pow- der. Finally the oral ulcerative disease of syphilis is likely to increase the nonsexual spread of human herpes virus 8 (HHV-8). ${ }^{46}$

\section{RESUMO}

Leão JC, Gueiros LA, Porter SR. Manifestações Orais da Sífilis. Clinics. 2006;61(2):161-6.

A última década tem mostrado um aumento importante na prevalência de sífilis infecciosa nos países desenvolvidos e epidemias surgiram na Europa ocidental, particularmente no Reino Unido, bem como nos EUA. Embora as manifestações orais da sífilis sejam mais freqüentes na fase secundária da doença, todos os estágios podem apresentar lesões orais. A fase terciária da doença está associada a lesões orais significativas tais como destruição óssea associada à goma sifilítica e uma possível predisposição ao carcinoma espinocelular. Com o aumento da prevalência da sífilis infecciosa, há também um aumento gradual de crianças nascidas com sífilis congênita. Consequentemente esta patologia leva a anomalias faciais de ordem dentária, óssea, dermatológica e neurológica. O objetivo deste artigo é revisar as lesões orais associadas á sífilis, bem como discorrer brevemente sobre a relação entre a infecção pelo vírus da imunodeficiência humana (human immunodeficiency virus - HIV) e a sífilis.

UNITERMOS: Sífilis. Sífilis congênita. HIV. Doenças transmissíveis.

\section{REFERENCES}

1. Dupin N, Jdid R, N'Guyen YT, Gorin I, Franck N, Escande J P. Syphilis and gonorrhoea in Paris: the return. AIDS. 2001;15:814-5.

2. Fenton K A, Nicoll A, Kinghorn, G. Resurgence of syphilis in England: time for more radical and nationally coordinated approaches. Sex Transm Infect. 2001;77:309-10.

3. Hopkins S, Lyons F, Coleman C, Courtney G, Bergin C, Mulcahy F. Resurgence in infectious syphilis in Ireland: an epidemiological study. Sex Transm Dis. 2004;31:317-21.

4. Hughes G, Paine T, Thomas D. Surveillance of sexually transmitted infections in England and Wales. Euro Surveill. 2001;6:71-80.

5. Nicoll A, Hughes G, Donnelly M, Livingstone S, De Angelis D, Fenton $\mathrm{K}$, et al. Assessing the impact of national anti-HIV sexual health campaigns: trends in the transmission of HIV and other sexually transmitted infections in England. Sex Transm Infect. 2001;77:242-7.

6. Ashton M, Sopwith W, Clark P, McKelvey D, Lighton L, Mandal D. An outbreak no longer: factors contributing to the return of syphilis in Greater Manchester. Sex Transm Infect. 2003;79:291-3.

7. Koumans EH, Farley TA, Gibson JJ, Langley C, Ross MW, McFarlane $\mathrm{M}$,et al. Characteristics of persons with syphilis in areas of persisting syphilis in the United States: sustained transmission associated with concurrent partnerships. Sex Transm Dis. 2001;28:497-503.

8. Poulton M, Dean G L, Williams D I, Carter P, Iversen A, Fisher M Surfing with spirochaetes: an ongoing syphilis outbreak in Brighton. Sex Transm Infect. 2001;77;319-21.

9. Okwumabua JO, Glover V, Bolden D, Edwards S. Perspectives of lowincome African Americans on syphilis and HIV: implications for prevention. J Health Care Poor Underserved. 2001;12:474-89.
10. Lopes F, Latorre MR, Campos Pignatari AC, Buchalla CM. HIV, HPV, and syphilis prevalence in a women's penitentiary in the city of Sao Paulo, 1997-1998. Cad Saude Publica. 2001;17:1473-80.

11. Mindel A, Tovey SJ, Timmins DJ, Williams P. Primary and secondary syphilis, 20 years' experience. 2. Clinical features. Genitourin Med. 1989;65:1-3.

12. Meljanac N, Dippel E, Zouboulis CC. Superimposed primary chancre in a patient with Adamantiades-Behcet's disease. Sex Transm Infect. 1999;75:124-5.

13. Neinstein LS, Goldenring J, Carpenter S. Nonsexual transmission of sexually transmitted diseases: an infrequent occurrence. Pediatrics. 1984;74: $67-76$

14. Ozturk F, Gurses N, Sancak R, Bay A, Baris S. Acquired secondary syphilis in a 6-year-old girl with no history of sexual abuse. Cutis. 1998;62:150-1.

15. Alam F, Argiriadou AS, Hodgson TA, Kumar N, Porter SR. Primary syphilis remains a cause of oral ulceration. Br Dent J. 2000;189:352-4.

16. Laskaris G. Oral manifestations of infectious diseases. Dent Clin North Am, 1996;40:395-423.

17. Kurien J, Kuriakose S. Doomed angels-a case report. J Indian Soc Pedod Prev Dent. 1997;15:10-12.

18. Thomas P, Schuck A, Meurer M, Kind P. Angina specifica and mucous plaques of the mouth cavity in lues II. Hautarzt. 1994;45:639-41.

19. Ban M, Ohtani M, Seishima M. A case of secondary syphilis with mucous patches on the hard palate. J Dermatol. 1995;22:52-54. 
20. Kleidermacher P, Vito KJ, Strome M. Otolaryngologic manifestations of acquired syphilis. Otolaryngol Head Neck Surg. 1998;119:399-402.

21. Mani NJ. Secondary syphilis initially diagnosed from oral lesions. Report of three cases. Oral Surg Oral Med Oral Pathol. 1984;58:47-50.

23. Meyer I, Shklar G. The oral manifestations of acquired syphilis. A study of eighty-one cases. Oral Surg Oral Med Oral Pathol. 1967;23:45-57.

23. Ficarra G, Zaragoza AM, Stendardi L, Parri F, Cockerell CJ. Early oral presentation of lues maligna in a patient with HIV infection. A case report. Oral Surg Oral Med Oral Pathol. 1993;75:728-32.

24. Rodriguez-Diaz E, Moran-Estefania M., Lopez-Avila A., Piris JB, Fernandez-Blasco G, Garcia JI, et al. Clinical expression of secondary syphilis in a patient with HIV infection. J Dermatol. 1994;21:111-6.

25. Sands M, Markus A. Lues maligna, or ulceronodular syphilis, in a man infected with human immunodeficiency virus: case report and review. Clin Infect Dis. 1995;20:387-90.

26. Baniandres RO, Nieto PO, Moya AL, Carrillo GR, Harto CA Nodular secondary syphilis in a HIV patient mimicking cutaneous lymphoma]. An Med Interna. 2004;21:241-3.

27. Huebsch RF Gumma of the hard palate, with perforation; report of a case. J Oral Surg. 1955;8:690-3.

28. Kirwald H, Montag A. Stage 3 syphilis of the mouth cavity. Laryngorhinootologie.1999;78:254-8.

29. Ramstad T, Traaholt L. Destruction of the soft palate and nose by tertiary 'benign' syphilis. A case report. J Oral Rehabil. 1980;7:111-5.

30. Taylor RG, Hipple W. Gumma of palate with negative standard tests for syphilis. Oral Surg Oral Med Oral Pathol. 1961;14:788-92.

31. Trieger N, Ship II, Taylor GW, Weisberger D. Cirrhosis and other predisposing factors in carcinoma of the tongue. Cancer. 1958;11:35762.

32. Michalek AM, Mahoney MC, McLaughlin CC, Murphy D, Metzger BB. Historical and contemporary correlates of syphilis and cancer. Int J Epidemiol. 1994;23:381-5.

33. Dickenson AJ, Currie WJ, Avery BS. Screening for syphilis in patients with carcinoma of the tongue. Br J Oral Maxillofac Surg. 1995;33:31920 .
34. Keane JR. Melkersson's syndrome associated with syphilis. J Clin Neuroophthalmol. 1988;8:249-53.

35. Housego T, Wood RE, Grotepass F, Nortje CJ. Repair of a palatal defect associated with late congenital syphilis using a tongue flap. J Oral Maxillofac Surg. 1998;46:70-3.

36. UNAIDS. Epidemiological fact sheets on HIV/AIDS and sexually transmited Infections: Brazil, 2004. 2004:1-20.

37. Nnokura EN, Ezeoke ACJ. Evaluation of syphilis in patients with HIV infections in Nigeria. Trop Med Int Health. 2005;10:58-64.

38. Johns DR, Tierney M, Felsenstein D. Alteration in the natural history of neurosyphilis by concurrent infection with the human immunodeficiency virus. N Engl J Med. 1987;316:1569-72.

39. Kumar B, Gupta S, Muralidhar S. Mucocutaneous manifestations of secondary syphilis in north Indian patients: a changing scenario? J Dermatol. 2001;28:137-44.

40. Kumar B, Muralidhar S. Malignant syphilis: a review. AIDS Patient Care STDS. 2001;12:921-5.

41. Kumwenda NI, Taha TE, Hoover DR, Markakis D, Liomba GN Chiphangwi JD, et al. HIV-1 incidence among male workers at a sugar estate in rural Malawi. J Acquir Immune Defic Syndr. 2001;27:202-8.

42. Clottey C, Dallabetta G. Sexually transmited diseases and human immunodeficiency virus, epidemiologic synergy. Infec Dis North Am, 1993;7:753-70.

43. Sadig ST, McSorley J, Copas AJ, Bennett J, Edwards SJ, Kaye S, et al The effects of early syphilis on CD4 counts and HIV-1 RNA viral loads in blood and semen. Sex Transm Infect. 2005;81:213-6.

44. Mbopi-Keou FX, Belec L, Teo CG, Scully C, Porter SR. Synergism between HIV and other viruses in the mouth. Lancet Infect Dis. 2002;2:416-24

45. Faruque S, Edlin BR, McCoy CB, Word CO, Larsen SA, Schmid DS, et al. Crack cocaine smoking and oral sores in three inner-city neighborhoods. J Acquir Immune Defic Syndr Hum Retrovirol. 1996;13:87-92.

46. Cook RD, Hodgson TA, Waugh AC, Molyneux EM, Borgstein E, Sherry A, et al. Mixed patterns of transmission of human herpesvirus- 8 (Kaposi's sarcoma-associated herpesvirus) in Malawian families. J Gen Virol 2002; 83: 1613-9. 